A new management model for public utility companies

\section{Innovativeness as a condition for business excellence}

Erfolgreich zu sein ist das Ziel jedes Unternehmens. Aber den richtigen Weg zum Erfolg zu wählen ist bereits ein Problem. So sind bei der Wahl eines Führungsmodells in öffentlichen Versorgungsunternehmen spezifische Faktoren zu berücksichtigen. Ein neues Managementmodell, entwickelt vor dem Hintergrund eines Transformationslandes, trägt diesen Anforderungen Rechnung. Von Branko Škafar

ga present conditions, the survival of organisations depend on the level of their competitiveness, which is expressed in their success. Innovativeness, also expressed in excellent quality products, procedures and services is the condition of competitiveness (Mulej 1994). Due to rapid changes in market and technology, management has to deal with an increasing number of problems. Research has shown that good companies try to tackle this problem by using more than ten basic managerial techniques at the same time. One model to achieve busisness excellence is the European Quality Award Model (EQA-EFQM).

\section{Innovation in public-utility companies in Slovenia}

Transition in Slovenia may be finished institutionally but not practically, since the innovation of culture and business practice based on this culture is not finished yet. On the basis of the analysed literature, and through a survey, we found that public-utility companies in Slovenia, as an example of a country in transition, pay little attention to innovation and business excellence. For example, according to the innovativeness index calculated by Deloitte \& Touch, Slovenia lags behind Estonia, Czech Republic, Hungary, Slovakia, and also most West-European countries. It achieves particularly poor results on some of the ten indicators constituting the innovativeness index. In general, Slovenian companies only started addressing this issue with the introduction of standards according to the Quality System ISO 9001 into some public-utility companies.

\section{Moving beyond the Euro- pean Quality Award Model}

The old Slovenian Business Excellence Prize (PRSPO) and EFQM Models do not lay special stress on innovation and motivation, whereas the new PRSPO and EFQM Models, which have been established in the recent years, already point out innovation. Before this background, the question is, if the EQA-EFQM is suited for the situation in tranistion countries in general and if it meets the specific needs of public-utility companies in particular.

So based on the EQA-EFQM, or its derivative, the PRSPO Model, we tried to draw up and propose a new model which is directly tailored to the needs of publicutility companies. The proposed model was developed in the company Saubermacher and Komunala.

Through a comparative and also quantitative analysis of data of public-utility companies, we also tried to prove the thesis that the presented model is appropriate for public-utility companies, especially in transition conditions typical of Slovenia.

The company should first lay the foundation, where the processes and efficient working procedures should be defined. These could be laid down in a manual to show that there is order in the company.
Order could be achieved by obtaining the ISO 9001 Quality Certificate. As the activities of public-utility companies concern the environment, considering sustainable development is a must, or else the consequences could be disastrous for both the environment and the service users. The environmental management system, ISO 14001, could be very useful here. For approaching business excellence, PRSPO or EQA Models could be used. These would help in self-assessment, while external experts would investigate the progress on the way to business excellence.

\section{A new business excellence model}

The Quality System (ISO 9001), the Environmental Management System (ISO 14001), the Social Accountability System (SA 8000) as well as the Health and Safety at Work System, already constitute a part of the PRSPO and EQA models. It is essential that all these systems are integrated to serve as a prototype of the company's functioning. Since publicutility companies deal with the natural environment and are as such under the watchful eye of the public, ethics are vital to a long-term effective performance. The companies are therefore recommended to draw up their own Codes of Ethics.

Of course this is far from enough. In practice procedures can be written down and set up in no time with the help of external consultants. However, these documents will not come to life, if people, especially the management, do not make them their own. Ambitious, motivated, innovative, and business-excellence-oriented management is a key factor for a successful process.

\section{Motivation as a key to innovation}

When the management of a company is success-oriented and it has ethically designed principles, which it practices, it will be strongly trusted by people. And if such management encourages creativity in its people and offers them freedom and possibility of generating ideas, they will 
in fact generate many ideas, improvements and other innovations. Innovation will be present in all activities within the company, from managing and organising to motivating and service providing.

Motivation is one of the pillars of the model. Only motivated and competent people are the source of innovation and partners in the organisation's business excellence. Adaptable people with proper education and training will generate promising ideas more often, and will be more open to the ideas of others. The company's culture and its innovative image will help attract and keep innovative staff (Trott 2003). People diversity in terms of knowledge, experiences, personal features and cultures will also have a positive impact on the improvement of innovation potential (Hylland et al. 2001). Continuous changes will occur and lead to business excellence, which can also be reached through strategic planning and implementing the plans.

The proposed original model differs from the EQA-EFQM Model in that a complete range of interdependent factors is important to attain business excellence, including products or services, procedures, committed people, co-operative leaders and an organisation that will hold all these together.

\section{Conclusion}

To summarise, the essence of the proposed model lies in the control of innovativeness in all fields, and in motivation. There is great emphasis on communication, which is the basis of good co-operation. Written business performance rules, in our case ISO 9001, ISO 14001, SA 8000 and OHSAS 18001, with continuous improvements, the PRSPO or EQA Model, business ethics and sustainable development, are the foundations on which inovativeness, motivation, communication and continuous changes are based.

The model also takes into consideration that due to the specific nature of public-utility companies, management pressure should be stronger than market pressure, and that the organisation will only be excellent when both its service

and procedures are excellent, when management is cooperative and committed. Innovative business should be achieved.

By testing the model in practice and by carrying out a quantitative analysis we have proven that the model is appropriate for public-utility companies in economies in transition to attain business success. We found, that this model is more useful and successful for public-utility companies than the PRSPO and EQAEFQM Models, because it is specificly designed for the activities of public-utility companies in countries in transition, and because it stresses innovativeness more, which is the basis of a company's success and existence.

\section{Literature}

Florida, R.: The rise of the Creative Class. IPAK, Velenje 2005.

Hylland, W. / Paul, J. / Gieskes, F.B.: Occupational Clusters as Determinants of Organisational Learning in the Product Innovation Process. In: Journal of Work place learning (online). Dosegljivo 2001. Internet: http://www. emerald-library.com/ft.

Mulej, M.: Innovation management. EPF, Maribor 1994.

Trott, P.: Innovation management and New Product Development. Prentice Hall 2003.

I AUTOR + KONTAKT

Dr. Branko Škafar ist Geschäftsführer von Saubermacher-Komunala und Mitarbeiter am Doba College of Business in Maribor.

Saubermacher-Komunala, Kopališka ul 2, 9000 Murska Sobota, Slovenien. E-Mail: branko.skafar@siol.net, Internet: www.saubermacher-komunala.si

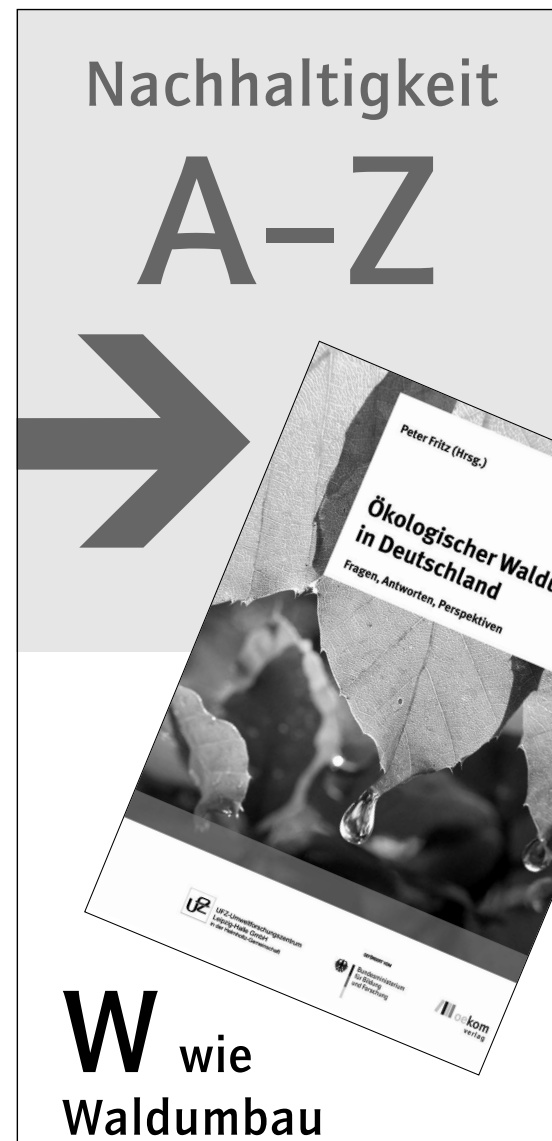

Der ökologische Waldumbau in Deutschland ist eine Jahrhundertmaßnahme. Welche Entwicklungen können angestrebt, welche Konsequenzen müssen berücksichtigt werden? Welche Folgen ergeben sich im Einzelnen, z. B. für Artenvielfalt, die Böden, die Atmosphäre oder den Wasserhaushalt?

Dieses Handbuch stellt die Zielkonflikte des ökologischen Waldumbaus umfassend dar, bietet Auswege und liefert detailliertes Wissen, kompakt und verständlich aufbereitet.

P. Fritz (Hrsg.)

Ökologischer Waldumbau in Deutschland

Fragen, Antworten, Perspektiven

oekom verlag, München 2006, 352 Seiten (mit zahlreichen farbigen Fotos und Grafiken) 29,80 EUR, ISBN 978-3-86581-001-4

\section{Erhältlich bei}

www.oekom.de

oekom@de.rhenus.com

$\mathrm{Fax}+49 /(0) 81$ 91/970 00-405

\section{/II oekom verlag}

Die guten Seiten der Zukunft 
(c) 20I0 Authors; licensee IÖW and oekom verlag. This is an article distributed under the terms of the Creative Commons Attribution Non-Commercial No Derivates License (http://creativecommons.org/licenses/by-nc-nd/3.o/), which permits unrestricted use, distribution, and reproduction in any medium, provided the original work is properly cited. 